\title{
Italy introduces performance-related funding
}

The Italian government has finally given the go-ahead to a national research evaluation agency, ANVUR. But at the same time it published Italy's first university ranking and said performancerelated funding would begin immediately.

The 24 July announcement of ANVUR was welcomed by many scientists who say that the country has not adequately rewarded bestperforming research institutions. A law creating the agency was passed two years ago, but not put into practice until now. ANVUR should start work in about a year, says Mariastella Gelmini, the minister of universities and research.

Her ranking of universities caused political outcry however. Up to $7 \%$ of the approximately $€ 7$-billion (US\$10-billion) national university budget will be allocated according to the list. Universities in the centre and north of the country generally did well, but most universities in the poorer south ranked at the bottom.

The ranking was based on an internal research evaluation carried out several years ago, combined with other criteria intended to assess teaching quality.

Raffaele Lombardo, president of Sicily, denounced the ranking criteria as discriminatory. Poor infrastructure in many southern universities prevents them from attracting independent research funds, he said in newspaper interviews, and high unemployment rates make it hard for graduates to find jobs, a criterion used to measure effectiveness of teaching. Lombardo and others also criticized the use of old bibliometric data.

All universities are concerned that performance-related funding is being introduced in a year when the government plans a $10 \%$ cut in the university budget. Davide Bassi, rector of the top-ranking University of Trento, says that this will be a "disaster for all universities, including our own".

Details of ANVUR's operation have yet to be set, but it is likely to be responsible for fine-tuning the criteria used in ranking exercises. Alison Abbott

\section{Forest growth studies begin to turn up the heat}

Across the United States, researchers are firing up experiments to determine how rising temperatures could reshape the nation's forests.

The studies encompass the pines and maples of eastern forests in Massachusetts and North Carolina, the spruce and fir of northern Minnesota, and the alpine tundra ecosystem above the treeline in the Rocky Mountains in Colorado.

Technology to warm soils is more than a decade old, but altering the temperature above ground remains challenging, particularly in a forest. "People criticize just warming the soil, but it's difficult to warm stands of relatively large trees," says ecologist Scott Bridgham, of the University of Oregon in Eugene. "Researchers have tended to shy away from forests.” But as the US Department of Energy phases out a number of large-scale forest experiments designed to look at the effects of elevated carbon dioxide levels (see Nature 456, $289 ; 2008)$, researchers are clamouring for the next generation of experiments to incorporate temperature control.

For now, the technology available limits such projects to seedlings and young trees on relatively small plots of land. That will still be informative, says Jacqueline Mohan, an ecologist at the University of Georgia in Athens. "The most important determinant of where a species can grow is where the juvenile trees can grow and thrive," she says.

In the next few weeks, Mohan and her colleagues, including Jerry Melillo of the
Marine Biological Laboratory in Woods Hole, Massachusetts, will switch on a series of underground heating cables and above-ground, open-topped heating chambers in Harvard Forest, located in Petersham, Massachusetts, and Duke Forest, which spreads across several counties in North Carolina.

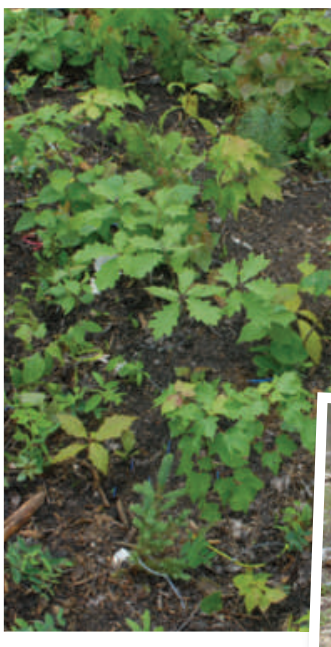

Warmed plots show spring greening (right) taking place earlier.

Meanwhile, in Minnesota, Peter Reich, a forest ecologist at the University of Minnesota in St Paul, and his colleagues switched their heaters on in April. Measurements on 1,500 of the 10,000 seedlings his team has planted suggests that a rise of $2-4^{\circ} \mathrm{C}$ causes seedlings to put out shoots and leaves earlier in the year. These effects differ across the 11 species that Reich's team is testing, giving an early clue to one mechanism by which increased temperatures can alter the balance of power in a forest.

Later this summer, an experiment in the Rocky Mountains led by Lara Kueppers, an ecologist at the University of California, Merced, will begin heating three sites one in the alpine tundra above the treeline, one at the edge of the treeline and a lower site within the forest. Her team will also look at how genetic variation and moisture affect which species fare best in higher temperatures.

The teams are using different methods to warm the air. Melillo and Mohan circulate water, heated by propane, in the walls of open-topped chambers. Reich and Kueppers use infrared heating lamps, which have the advantage of not enclosing the sides of test plots, but the disadvantage of heating surfaces directly, rather than simply raising the air temperature.

Many unknowns remain, however. "None of us," says Reich, "really knows whether the way that we're warming will have some effects that might be different from the way that nature will warm forests in the future." Heidi Ledford 